\title{
Discourse particles in Manado Malay ${ }^{*}$
}

\author{
Ruben Stoel \\ Universiteit Leiden/HIL
}

\section{Introduction}

This paper is a first attempt to analyze the meaning of the discourse particles in Manado Malay, of which there are about twenty. Most of these particles occur very frequently, but their exact meaning is difficult to state. The analysis presented here is based on data gathered in fieldwork carried out in 1998-99.

Manado Malay is the language of Manado, the capital of the Indonesian province of North Sulawesi. It is also spoken in many other areas of Sulawesi, either as a first or second language. Although Manado Malay is closely related to some other varieties of Malay spoken in eastern Indonesia, none of them seem to have the rich variety of discourse particles found in Manado Malay.

Very little has been published so far on Manado Malay. Basic information on the grammar is given in Karisoh Najoan et al. (1981), and in Prentice (1994), who also discusses phonology, but no attention is paid to the discourse particles. Many examples of the particles can be found in the illustrative sentences in the dictionary of Salea-Warouw (1985), but their meaning tends to get lost in translation. In another article, Salea-Warouw uses the term casual particles ('partikel santai') for some of these particles, because they function as code-labels for a casual style of speaking (1986:242).

All the examples in this study are taken from spontaneous speech. Eighteen dialogues of about five minutes each were recorded, and transcribed with the assistance of Lusiana Musa, a native speaker of Manado Malay. Most of the speakers were students from the Sam Ratulangi university in Manado, or the teacher training college in Tondano, and they were free to talk about whatever they liked. In addition, I always carried a small notebook, and whenever I heard a useful sentence, I tried to write it down.

In the following section I will present a survey of the discourse particles, and in Section 3 something will be said about their possible origins. 


\section{Classification and meaning}

The discourse particles in Manado Malay can be defined as follows: 1. they are either the last word of a phrase (e.g. a NP or VP), or they follow a clause-initial conjunction; 2. they cannot occur in isolation; 3 . they are syntactically optional; and 4. they are never accented. This last point needs some clarification. In Manado Malay, the sentence accent always falls on the last word of a phrase. But if this phrase ends in a discourse particle, then the accent falls on the word preceding the particle. Although the discourse particle itself is not accented, it may get an edge tone, depending on the function of the clause in the discourse. The particle kay, for example, which is used to form a tag-question, will normally be pronounced with a rising tone, since yes-no questions typically end in a rising tone.

Here, the discourse particles will be divided into four groups. For each particle, one or more example sentences will be given. Each example will be preceded by a short description of the context in which it was used. ${ }^{1}$

\subsection{Grounding particles}

The first group of particles to be discussed will be called grounding particles. The particles in this group indicate that the clause in which they occur constitutes either foreground or background information. Foregrounded clauses supply the main points of a discourse, and cannot be left out without causing incoherence. Backgrounded clauses merely amplify or comment on the foreground (Hopper and Thompson 1980:280).

\begin{tabular}{lll}
\hline Grounding particles & $\begin{array}{l}\text { Dependent on } \\
\text { preceding discourse }\end{array}$ & $\begin{array}{l}\text { Dependent on } \\
\text { following discourse }\end{array}$ \\
\hline $\begin{array}{l}\text { backgrounding } \\
\text { foregrounding }\end{array}$ & kan & to \\
\hline
\end{tabular}

There are two particles that mark backgrounding, kan and to. Clauses with kan supply supporting information to a preceding clause in the discourse. Two examples are given below. The sentence in (1) makes clear why the previous sentence was relevant: since the speaker was going out with some other people, it could be expected that they would wait for him. The sentence in (2) gives an explanation: the products have to be made in Java, since there is no factory in Manado.

(1) They didn't wait for us.

Oran laen kan bakubawa sama-sama den toran.

man other PART go.out together with 1PL

'After all, the others were going out together with us.' 
(2) All these clothes are made in Java.

Pa toran kan di Manado sini bulún da fabrik.

at 1PL PART in Manado here not.yet there.is factory

'Here in Manado we don't have a factory yet.'

If the speaker uses a kan-clause, he presents the information in it as something that is known to the addressee. In (1), the addressee knew, or was supposed to know, that the speaker was going out with another group. In (2), both speaker and addressee live in Manado, and they know well that there are no factories for making clothing there.

In most cases, kan follows the topic of a clause. But kan may also follow a clause-initial conjunction, and it can even be the first word of a clause. Note that this is the only exception to the first rule given at the beginning of Section 2. Kan is never the last word of a clause.

Clauses with to also supply background information, but this time in relation to a following clause. This is illustrated by the examples in (3)-(4), for which both the preceding and the following context is given. The information in (3) is relevant to the following sentence, because it reveals the contrast between the expectations of the speaker, and what happened in reality. In (4), the sentence gives an explanation of the subsequent sentence, i.e., the speaker thinks she must behave differently, because of the expectations imposed by the new environment.

(3) The gathering was over at last.

Ta harap-harap mo tidor to.

1sG hope INCH sleep PART

'I hoped we would stay.'

Mother ordered us to return that very night.

(4) We are not in high school anymore, but in college.

So laen to depe suasana.

PERF different PART 3sG.POss ambience

'The ambience is different.'

Now we must act like college students.

To is a focus particle: it always follows the focus expression of a clause. Thus to cannot be the last word in a sentence with a final topic, such as (4). If to comes at the end of a clause, it is pronounced with a rising tone. This tone is the well-known 'continuation rise', which indicates that there is more to follow.

Kan and to are often used simultaneously in a single clause, which then expresses background information in relation to both the preceding and the following discourse. The sentence in (5), for example, is a remark 'in parentheses', which helps the addressee to improve his understanding of the main line of the discourse. 
(5) Kiki left a message that she couldn't go.

Lusi kan səbənarna mo pigi den Kiki to.

Lusi PART in.fact INCH go with Kiki PART

'In fact, I (= Lusi) wanted to go out with Kiki.'

But her parents wouldn't let her go.

The particle day marks foregrounding. Whereas backgrounded clauses are dependent for their interpretation on a specific clause in the discourse, this is not necessarily the case for foregrounded clauses. Although a clause with dan always needs some background support for its complete understanding, this background may be derived from the extralinguistic context, rather than from discourse. This will become clear from the example in (10) below.

I will first discuss day-clauses that are dependent on discourse for their interpretation. These clauses give supplementary information about something mentioned in the preceding clause. Several types may be distinguished. Firstly, a clause with day can give a more specific description. For example, the sentence in (6) is a further description of 'driving fast'.

(6) He drove very fast.

Riki amper so mo tabrak-tabrak day. reach almost PERF INCH collide PART 'Almost leading to a collision.'

Secondly, a speaker can use a day-clause to correct himself, either because he realizes that what he said before is not fully correct, or, more often, because he was not able to think of the right word at once. An example of this last usage is given in (7).

(7) They often have no running water.

Bana e ... susa dan aer mo nae ka atas.

many uh difficult PART water INCH go.up to above

'There are many ... uh... it's difficult for the water to go uphill.'

Thirdly, a day-clause can be used to comment on the words of the addressee. This comment may be either a statement or a question. In the last case, day is pronounced with a rising tone, as is usual for yes-no questions. An example is given in (8).

(8) You must take the boat to go from Tahuna to Siau. $/ /^{2}$

$\mathrm{O} \quad$ noni di Tahuna dan?

INTERJ 2PL in Tahuna PART

'So you live in Tahuna?'

Fourthly, a day-clause can be used to announce a change in the topic of the discourse. The new discourse topic must belong to the same set as the topic of the preceding discourse. In (9), for example, the addressee, rather than the speaker, becomes the topic of the conversation. Both belong to the set of participants in the conversation, and day signals that the discourse will now be about an other member of this set. 
(9) I get on with my boyfriend very well.

Kon yana day ada cowo? le?

then 2SG PART there.is boyfriend PART

'And how about you, do you also have a boyfriend?'

Finally, the interpretation of a foregrounded clause with day may be dependent on the extralinguistic context, rather than on another clause in the discourse. In (10), for example, day indicates that a request for a beer is fully justified in the given situation, because western men are assumed to be rich, and so they should buy a drink for whoever asks for it.

(10) (A young girl approaches a western man in the disco:)

Bli akan bir dan!

buY BENEFACTIVE beer PART

'Buy me a beer!'

\subsection{Context-related particles}

The second group of discourse particles will be called context-related particles. They can be used to link the clause in which they occur to some aspect of the context. This may be a preceding or a following clause in the discourse, or something in the extralinguistic context.

\section{Context-related particles}

\begin{tabular}{ll}
\hline contrast & $k w a^{2}$ \\
alternative & $k e^{2}$ \\
addition & $l e$ \\
\hline
\end{tabular}

$K w a^{2}$ is a particle that signals a contrast. It warns the addressee that the information expressed in the clause may be something unexpected, given the current context. In (11), for example, the speaker blames the addressee for not doing what he promised to do, and there is thus a contrast between what the addressee said he would do, and what he actually did.

(11) It seems as if you only went there to have fun.

Bilan kwa? pi karjá.

say PART go work

'You said you went there to work.'

$\mathrm{Kwa}^{2}$ is not only used in statements, but also in commands and reprimands. By using $k w a^{2}$, the speaker can emphasize that there is a contrast between what he is saying and what the addressee is doing. It is thus suggested that the addressee should adjust his behavior. An example is given in (12). 
(12) (Seeing that her friend spills some water while pouring out.)

Plan-plan kwa?.

slow PART

'Do it slowly!'

$K w a^{2}$ can only occur at the end of the first prosodic phrase of an utterance. The particle itself is pronounced with a falling tone, which is both emphatic and marking a clear prosodic boundary.

The particle $k e^{2}$ indicates that the clause in which it occurs is only one of a number of alternatives. Two typical examples are given below. In the sentence in (13), two alternative choices are presented, and one or the other could be true. Although here only one of them is marked with $k e^{\text {? }}$, it is also possible for $k e^{\text {? }}$ to occur in two or more successive clauses. In (14), a construction with emplas ke? 'instead of' is used to reprove the addressee. Here, too, there are two alternatives: the words of the speaker describing an unreal event, and what happened in reality (i.e. not having bathed earlier).

(13) I heard you got a grant to study abroad.

Ta pikir Ibu so di Jerman ke?, ato di Kanada.

1sG think Mrs. INCH in Germany PART or in Canada

'I thought you were already in Germany, or in Canada.'

(14) Now we have missed the bus.

Emplas ke? mandi jo dari tadi!

instead PART bathe PART from before

'If you only had bathed earlier!'

The third particle in this group is $l e$ (also lei), which has an additive meaning. It indicates that the person, thing or property referred to is one more of its kind. There are two examples of $l e$ in the sentence in $(15){ }^{3}$ The first $l e$ merely doubles the concept expressed by sama 'same', but the second le points out that there is another person who has the property of being an adulterer. ${ }^{4}$

(15) In the long run, I am pretty sure my boyfriend will betray me. //

$\mathrm{O}$, samale, hele kitale pambahugal.

INTERJ Same PART since 1SG PART adulterer

'Oh, it's the same with me, since I am an adulteress too.'

$L e$ is often used in exclamations; an example is given in (16). A more in-depth study is needed here to establish whether this is a different particle from the one described above. $^{5}$

(16) We didn't go after all.

Untun le nana na? datan!

fortune PART 2SG not come

'Fortunately, you didn't come!' 


\subsection{Addressee-related particles}

The addressee-related discourse particles are used to elicit a response from the addressee. Three particles can be distinguished in this group: kay, ne and jo.

Addressee-related particles

\begin{tabular}{ll}
\hline request for confirmation & $k a \eta$ \\
softening & $n e$ \\
proposal & jo \\
\hline
\end{tabular}

The particle kay is a tag question, which is added after a statement in order to request a confirmation from the addressee. Kay is used if the speaker believes that what he is saying is true, and that it will be confirmed by the addressee. It is an attempt to draw the addressee into the conversation rather than an inquiry into truth. In (18), for example, the speaker already knew what had happened, but she merely wanted to hear the story one more time.

(18) This Andre is a funny guy.

na da bage depe kapala kan?

2sG real pat 3sG.poss head PART

'You patted him on the head, didn't you?'

Since kay forms a particular kind of yes-no question, it has the intonation that is characteristic for yes-no questions, i.e. a final rising tone.

The particle $n e$ is used to soften the mood of the addressee. A speaker will use it if he is doing, or plans to do, something that could potentially disturb the feelings of the addressee. In (19), for example, the speaker wants to go home after visiting a friend, and he must prevent his host from feeling being let down by his departure. In (20), the speaker has ordered Fanta in a restaurant, but then she decides she would rather like an other drink. As the waiter could feel offended by the cancellation of the order, the speaker uses ne to persuade him to give in.

(19) (A visitor wants to go home:)

Pigi ne.

go PART

'I would like to go.'

(20) (A woman in a restaurant has ordered Fanta, but then decides she would prefer something else. She calls the waiter and says:)

na? usa Fanta ne. Es joruk jo.

not need Fanta PART ice lemon PART

'Please forget about the Fanta. Make it lemon juice with ice.'

$\mathrm{Ne}$ is pronounced with a rising tone, which is characteristic for conciliatory utterances. 
The particle jo can be used to propose something to the addressee. In (20), for example, the speaker proposes to the waiter to bring her lemon juice. Depending on the context, a clause with jo may be a polite suggestion, or a straight command, as when talking to a child; see the example in (21). A speaker can also use jo to propose that he will do something himself, as in the sentence in (22).

(21) (Ordering a child to go:)

Pigi jo.

go PART

'Go away!'

(22) I will ask Alen when he is free.

Nanti ta pi pa depe ruma jo.

later 1 sg go at 3sG.poss house PART

'I will go to his house later.'

Less commonly, jo is used in yes-no questions, especially if a positive reply is expected. Although this may be a different particle from the one discussed above, it could still be called a kind of proposal: the speaker suggests that something might be the case, and the addressee is asked to confirm or reject this suggestion. In the sentence in (23), for example, the speaker suggests that the addressee likes her boyfriend, and asks whether this is true or not.

(23) My boyfriend is elder than me. //

Mar nana suka jo dia?

but 2sG like PART 3sG

'But you do like him?'

\subsection{Speaker-related particles}

The category of speaker-related particles contains all the discourse particles not discussed yet. These particles belong to the category of modality, and they are used to add a subjective comment toward the proposition expressed by the clause. Three subgroups are discerned here: particles that express judgments, evidentials and attitudes. For a general discussion of these categories I refer to Chapter 2 of Palmer (1986).

\subsubsection{Judgments/focus particles}

The particles no and sto are used to express the commitment of the speaker to the truth of the proposition expressed by the clause. No indicates that the speaker takes the proposition for granted, whereas sto is used if he is less certain. 
Judgments/focus particles

$\begin{array}{ll}\text { categorical assertion } & \text { no } \\ \text { hypothesis } & \text { sto }\end{array}$

No is used to make a categorical assertion. It can be used only in statements, and not in questions or commands. In (24), for example, the speaker states very explicitly that he has forgotten the last name.

(24) What is his last name?

Kita so lupa no depe fam itu.

1SG PERF forget PART 3sG.POss last.name that

'I have forgotten his last name.'

The position of no is determined by the information structure of the clause. No is a focus particle, since it must follow the phrase that expresses the focus of the clause. The word preceding no carries the main accent. In (24), the accent thus falls on lupa 'forget', and the final phrase depe fam itu 'his last name', which falls outside the focus domain, is unaccented. The speaker can assume that is still active in the consciousness of the addressee, because its referent has been mentioned in the preceding sentence.

No is used very frequently. One of the reasons for this could be that the accent in Manado Malay is generally quite weak, and therefore the focus domain is more clearly signaled by a particle. It is often appropriate to use no, since speakers tend to believe that what they are saying is true. No thus seems to be primarily a focus marker.

The particle sto (also stou or stau) indicates that the speaker is less convinced of the truth of the proposition expressed by the clause. It is only a guess, although it might very well be true. Sto is often used in combination with numerical values or time expressions, since it is often impossible or unnecessary to specify an exact value. See (25) for an example.

(25) What time did you arrive? //

Jam stena tiga sto.

hour half three PART

'At about half past two.'

Another example of sto is given in (26). Here the speaker is speculating about the feelings of one of her friends. Sto precedes the final pronoun, because it is a topic, and sto must follow the focus of a clause.

(26) Lob is angry that we are going out with Andre.

Com sto dia.

jealous PART 3sG

'He must be jealous.' 
Both no and sto are focus particles, but sto is used less frequently, because its meaning is more specific.

\subsubsection{Evidentials}

The evidentials form the second category of speaker-oriented particles. Evidential particles mark the nature of the evidence for a statement. Two particles belong to this category: the quotative kata, and the marker of direct experience kote?

\section{Evidentials}

quotative

kata

personal experience

kote?

Kata indicates that the speaker is reporting what someone else has said. The person from whom the speaker obtained this information could be mentioned explicitly, but his identity may just as well remain vague, as in case of hearsay. An example of the second possibility is given in (27). Here the speaker is outraged, because she has been accused wrongly of gossiping about the imminent divorce of her friend's sister.

(27) Her elder sister is getting a divorce.

Kon yoni dapa tau lantaran kita kata. then 2PL get know because 1sG PART

'You found out thanks to me, so they say.'

In (28), on the other hand, the person who reported the information is mentioned explicitly, and kata adds little to the meaning of the sentence. ${ }^{6}$ The combination of bilay 'to say' and kata in a single sentence is nonetheless quite common. Kata does not have to come immediately after bilay, and often it is the final word of the sentence. In that case bilay and kata act as the spoken equivalents of quotation marks.

(28) We were about to go home.

Kon Kristian bilan kata mo iko pa noni jo ka Sea?. then Kristian say PART INCH follow at 2PL PART to Sea 'And then Kristian said he wanted to follow you to Sea'

The particle kote? indicates that the speaker knows the information expressed in the clause through personal experience. It is only used for something unexpected that the speaker has just found out. This is illustrated by the sentence in (29). The speaker wants to go by bus, and she thinks it will be possible to get a seat. But once aboard, she soon discovers that all the seats are occupied. 
(29) (A passenger enters a bus to look for a seat, and sees that all the seats are occupied:) Fol kote?.

full PART

'It's full!'

Kote? is also used in hesitations, or when the speaker is looking for a word. It is then often abbreviated to $t e$ ?, and typically follows a question word, especially apa 'what'. It indicates that the speaker cannot find the right word for something he knows from his own experience. In the example in (30), the speaker knows that she saw the shoes her friend is looking for in a certain store, but she is not able to bring its name to mind at once.

(30) I know where you can find these shoes.

Kəmarin, ta da lia di ... apa tey ... Matahari...

yesterday 1 sg real see at what PART Matahari

'Yesterday, I saw at the... uh Matahari ...'

\subsubsection{Attitudes}

The particles that form the third category of the speaker-related particles are used to express the attitude of the speaker with respect to the statement being made. These particles are far less common than the ones discussed so far, and very few examples were actually recorded. The analysis of their meaning is therefore only preliminary. Four particles belong to this group: katu? tare?, komay and so.

\section{Attitudes}

contrary to what was expected contrary to how it should be disapproval of something done repeatedly expressing ignorance
katu?
tare?
komay
so

$\mathrm{Katu}^{2}$ emphasizes that the information in the statement is contrary to what was expected. In (31), for example, the speaker uses katu?, because she is shocked to hear that her friend is betraying her boyfriend. She expected her friend to be faithful, since her boyfriend is also faithful to her.

(31) Your boyfriend is faithful to you.

Kon katuy nana babahugal.

then PART 2SG have.an.adulterous.affair

'And yet you betray him.'

The particle tare? is used to emphasize that there is a contrast between what happened in reality, and the way it should have been. The sentence in (32) is uttered by a speaker who feels that she has not been treated fairly, because she did not get 
the opportunity to see the new calendar before it was hung on the wall, even though it was above all a present for her.

(32) Somebody has hung the new calendar on the wall.

Kita tare? blum lia.

1sG PART not.yet see

'(Even though) I didn't see it yet!'

Komay is used to disapprove of something done over and over again. The question in (33) is uttered because the speaker is annoyed about her little brother going out time after time: as soon as he comes home, he wants to go somewhere else.

(33) It would be better for my brother to stay home.

Pi mana koman?

go where PART

'Where is he going now?'

So is a particle used to express ignorance. This ignorance may be sincere, or the speaker may be just pretending. In (34), the speaker has met a very handsome man, and she asks her friend to tell her more about him. By emphasizing her ignorance with so, she makes it clear that she is very keen on hearing the answer to her question.

(34) He is a very handsome man.

Oran mana so dia?

man where PART $3 \mathrm{SG}$

'Where exactly is he from?'

\subsection{Combinations}

In all the examples above, there was only a single particle in a phrase, but combinations of two particles are quite common. The meaning of a particle group is the sum of the meaning of the individual particles. Unfortunately, there is no space here to give examples. The following combinations have been attested:

day kan, day to, day ne, day kata, day katu?

$k w a^{2}$ kay

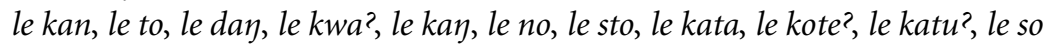

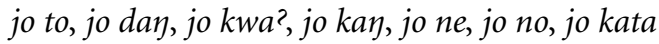

no kay, no katu?

sto kwa?, sto kay, sto no, sto katu?

Only day, le, jo, no and sto occur regularly as the first particle of a group. Note that the order of the particles is not determined by their semantic class, e.g. jo is always the first particle, but the other addressee-related particles, kay and ne, come last. The acceptability of other combinations will be tested in further research. 


\section{Origin}

Many of the discourse particles in Manado Malay are not found in the other varieties of Malay. The origin of some of them can be traced without problems, but

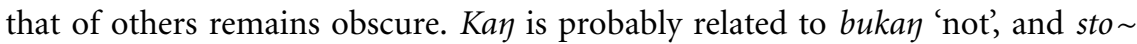
stou stau may be derived from tau 'to know'. The quotative kata also has the meaning 'word', and in other varieties of Malay it is the root of the verb 'to say'. The particles le $\sim$ lei and jo correspond to lai lagi 'again, still', and jua juga 'also' in other varieties of Malay. The particle $k e^{2}$ also occurs in Jakarta Malay. To and day are borrowed from Dutch toch 'still' and dan 'then', and ne might be a loan from the Japanese ne, which is used to elicit agreement from the listener. The origin of the other particles is not known to me; they do not appear to be loans from any language of North Sulawesi.

\section{Conclusion}

A survey of the discourse particles in Manado Malay has been given, and their meaning has been discussed. More research is needed in order to give a more detailed account. Especially the particles that express attitudes require a more indepth investigation. A more systematic study of the relation between the position of the particles in the clause and its information structure is also desirable.

\section{Notes}

* This research was funded by the Royal Netherlands Academy of Arts and Sciences (KNAW) as part of the project 'Phonetics and phonology of prosodic systems in the languages of Indonesia' (grant \#95-CS-05, principal investigators V. J. Heuven \& W.A. L. Stokhof). I am thankful to an anonymous reader for many useful comments.

1. The following abbreviations are used in the glosses: 1, First person; 2, Second person; 3, Third person; CAUS, causative; INCH, Inchoative aspect; INT, Intensifier; INTERJ, interjection; PART, Discourse particle; PERF, Perfective aspect; PL, Plural; POss, Possessive marker; sG, Singular.

2. The symbol ' $/ /$ ' is used to signal a change of speaker.

3. See the sentence in (9) above for another example of $l e$.

4. Note that there are no grammaticalized gender-distinctions in Manado Malay.

5. Cf. the difference in Indonesian between lagi and lah, as in the expressions satu lagi 'one more' and $u n t u$ ? lah 'fortunately'.

6. The reading 'They say Kristian said ...' is not intended here. 


\section{References}

Hopper, Paul J. and Sandra A. Thompson (1980). 'Transitivity in grammar and discourse'. Language 56, 251-299.

Karisoh Najoan, J.A., et al. (1981) Morfologi dan sintaksis bahasa Melayu Manado. Pusat Pembinaan dan Pengembangan Bahasa, Jakarta.

Palmer, F. R. (1986) Mood and modality. Cambridge University Press, Cambridge.

Prentice, Jack (1994) 'Manado Malay: Product and agent of language change'. In Tom Dutton and Darrell T. Tryon, eds., Language contact and change in the Austronesian world. Mouton de Gruyter, Berlin, 411-441.

Salea-Warouw, Martha (1985) Kamus Manado - Indonesia. Pusat Pembinaan dan Pengembangan Bahasa, Jakarta.

Salea-Warouw, Martha (1986) 'Variasi bahasa Manado'. In H. Kridalaksana, ed., Pengembangan ilmu bahasa dan pembinaan bangsa. Nusa Indah, Ende, Flores, 238-250. 